\title{
Geospatial Monitoring on Land Surface Temperature and Vegetation Dynamics: A Case of a City Area in Khulna, Bangladesh
}

\author{
MD. NAZMUL HAQUE*, NOWRIN RAHMAN KHANAM \& MEHNAZ NANJIBA
}

\author{
Department of Urban and Regional Planning, Faculty of Civil Engineering, Khulna University of Engineering \& \\ Technology, Khulna -9203, Bangladesh \\ *Corresponding author: nhaque13@urp.kuet.ac.bd
}

\begin{abstract}
Land surface temperature and vegetation cover are two important parameters to evaluate the climate change and environmental condition. The current study is carried out in respect of monitoring the changing phenomena of climate and environment. The area selected to conduct the study was ward number 1, 2 and 3 of Khulna City Corporation), from the third largest city of Bangladesh. This study is corresponding through the calculation of Land Surface Temperature (LST) and Normalized Differential Vegetation Index (NDVI) for two different years, 2010 and 2018. LST and NDVI are observed to realize the association between surface temperature and amount of vegetation. With the help of ArcGIS 10.5, LST and NDVI calculations are done using Landsat 5 Thermal Mapper, Landsat 8 Operational Land Imager and Thermal Infrared Sensor images (for 2010 and 2018, respectively) collected from USGS Earth Explorer. The findings of the study specify that the highest temperature in 2018 is $32.5^{\circ} \mathrm{C}$ in ward 2 and in 2010 it was $27.5^{\circ} \mathrm{C}$ in ward 3, though the overall vegetation amount decreased in 2018, About 18, 900 square meter of very low canopy area has increased in ward 3 from the period of 2010 to 2018 and in the same time 35, 100 square meter of low canopy area has been decreased for the overall study area. However, parts of the study area of ward no. 3 had faced a significant increase in vegetation cover which is the cause of low temperature compared to ward 1 and 2 in 2018.
\end{abstract}

Keywords: LST, NDVI, Surface Temperature, Vegetation.

Copyright: This is an open access article distributed under the terms of the CC-BY-NC-SA (Creative Commons Attribution-NonCommercial-ShareAlike 4.0 International License) which permits unrestricted use, distribution, and reproduction in any medium, for non-commercial purposes, provided the original work of the author(s) is properly cited.

\section{INTRODUCTION}

Bangladesh is a fast-developing country which is aiming to be a developed country very soon. Bangladesh is lying at the front line of climate change which is a global challenging issue in $21^{\text {st }}$ century (Islam, Islam, Chakraborty \& Alam, 2019). The geographical location and hydro-meteorological situation have made Bangladesh vulnerable to the climate change (Esha \& Ahmed, 2018). The process of development, urbanization and industrialization, have made the environment and ecosystem to come at a risk, which is also being disturbed at a high rate and this may be a threat to the population of the country. Among the cities of Bangladesh, Khulna is the third largest one (BBS, 2011). Besides, the city is also developing day by day. The construction of Padma Bridge will fasten the development process of the city which might result in more cutting down of trees and rise in temperature. Thus, the goal of the prerequisite is to analyze the land surface temperature and vegetation covering to the selected wards of Khulna comparing over two years which may help in further management of environment in the area. The objective was to analyze the environmental surface temperature condition focusing on the amount of the vegetation through the GIS and remote sensing approach.

Vegetation index is a quantitative way of measuring the vegetation vitality using different combination of red and infrared bands. Among many other vegetation indices, Normalized Differential Vegetation Index (NDVI) is widely used for vegetation cover estimation, productivity assessment, variation in trend assessment of vegetation (Jiang et al., 2006; Li, Liu, Cao \& Xue, 2015). NDVI values differing from -1 to 1 indicate different land conditions for land cover. Here, negative values around -1 stand for water. Near zero values represent sand, snow or rock, positive values around 0.2 - 0.4 stand for grass and shrub and high positive values near 1 represent temperate and tropical rainforests (Babu, Hemalatha \& Naik, 2016; Kovalev \& Tokareva, 2016; Li et. al., 2015; 
Weier \& Herring, 2000). The skin temperature of the earth surface, which can be measured from ground and satellite data, have great influence on physical, biological and chemical process like heat and energy exchange between the surface and the atmosphere, can be demarcated as land surface temperature (LST) (Mia, Bhattacharya \& Woobaidullah, 2017; Paruelo, Epstein, Lauenroth \& Burke, 1997).

Song et al., (2018) have featured other studies to analyze the relationship between the LST and NDVI. The northeastern part of Guizhou Province in China is a karst area, has shown an opposite pattern of spatial distribution of LST and NDVI across the area. North America has shown seasonal difference of relationship between LST and NDVI. Positive relationship can be seen in cold season and negative relationship in the warm season. Some studies have researched on drought according to the monitoring of the LST and NDVI (Deng et al., 2018; Fathizad, Tazeh, Kalantari \& Shojaei, 2017; Wang et al., 2011; Zhao, Cong, He, Yang \& Qin, 2017).

Esha \& Ahmed (2018) and Islam et al., (2019) have demonstrated the necessity of sharing an integrated approach to analyze and assess the spatio-temporal land cover monitoring along with temperature in north-western region of Bangladesh. Esha \& Ahmed (2018) have done the assessment of finding the relation between LST with NDVI through the GIS approach of making NDVI and LST maps.

Islam et al. (2019) have conducted their research in the Khulna Metropolitan area, considering the year 2001, 2011 and 2018. It is clearly revealed that LST has increased over the time and land cover have also changed towards to the urban built up area (Islam et al., 2019). Mondal and Uddin (2018) have conducted a research in the drainage basin of Atai-Bhairab-Rupsha river confluence, which covers mainly Khulna district. Due to the barren soil area, highest temperature was greater during the year of 1995 than 2006 and 2015. Temperature has increased at a significant level in the year 2015 than 2006. This can be an indication of the transformation of the barren soil area into urban built up area during the time period of 2006-2015 (Mondal \& Uddin, 2018).

Although there are studies that address various issues of geospatial techniques to investigate the dynamics of land surface, but they have some common limitations. For instances, the first group of studies examined the role of geospatial tools in broad perspective (Anandababu, Purushothaman \& Suresh Babu, 2018; Avdan \& Jovanoska, 2016; Grover \& Singh, 2015; Guha \& Govil, 2020; Li et al., 2015; Saha, Paul, Gupta \& Saha, 2016; Song et al., 2018; Tran et al., 2017). The second group of studies (Islam et al., 2019; Mia et al., 2017; Mondal \& Uddin, 2018; Shimu et al., 2019; Uddin \& Mondal, 2020) explored the factors that affects the land surface elements in city/regional territory. Very few studies address the monitoring issues from very micro unit often in ward boundary setting. Additionally, some of them put sophisticated weight on the impact of climate change on the dynamic behavior, a bit intuitive in nature with limited practical perception. Very light efforts are observed to address the assessment of geospatial monitoring on LST and NDVI in a temporal scale, especially in urban unit context. This research fills these gaps in numerous ways by fixing Khulna city corporation as a candidate study area.

In this sense, the research will contribute by assessing the land surface behavior with the vegetation health in geospatial environment in a very micro perspective. Geospatial environment can help to connect the realworld scenario through the satellite image. Again, Satellite based LST mapping has a wide range of application in the field of science and technology such as for deducting climate change pattern, land/atmospheric feedback or modelling studies, monitoring and prediction of land cover changes, for the use of crop and water resource management, for geological applications and so on (Tashnim \& Anwar, 2016). NDVI is a measurement of plant health, as how a plant reflects light at any specific frequency (Raynolds, Comiso, Walker \& Verbyla, 2008). Bare soil, waterbody and built-up area, plants under stress, crops and crops stage are fully detectable through NDVI (Li et al., 2015). Hence it will help to visualize the actual fact/scenario from bottom-up approach and help to take decision locally to monitor the issues. 


\section{METARIALS \& METHODS}

\section{Exploring the research area}

Among the cities of Bangladesh, Khulna is the third largest one, located at the south-west region. Khulna is a renowned river port situated by the bank of rivers, Bhairab and Rupsha. It is the centre of industrial prosperity of Bangladesh and many national companies depend on it. The encompassing Khulna City Corporation (KCC) had a projected population of 1.022 million in 2014 whereas the population of Khulna is 1, 342, 339 in the year of 2019 (World Population Review, 2019). The northern most area of the Khulna Metropolitan city, is the location of Ward No. 1, 2, 3. Figure 1 displays the location of study area and Table 1 shows the area and population of each ward under the study area.

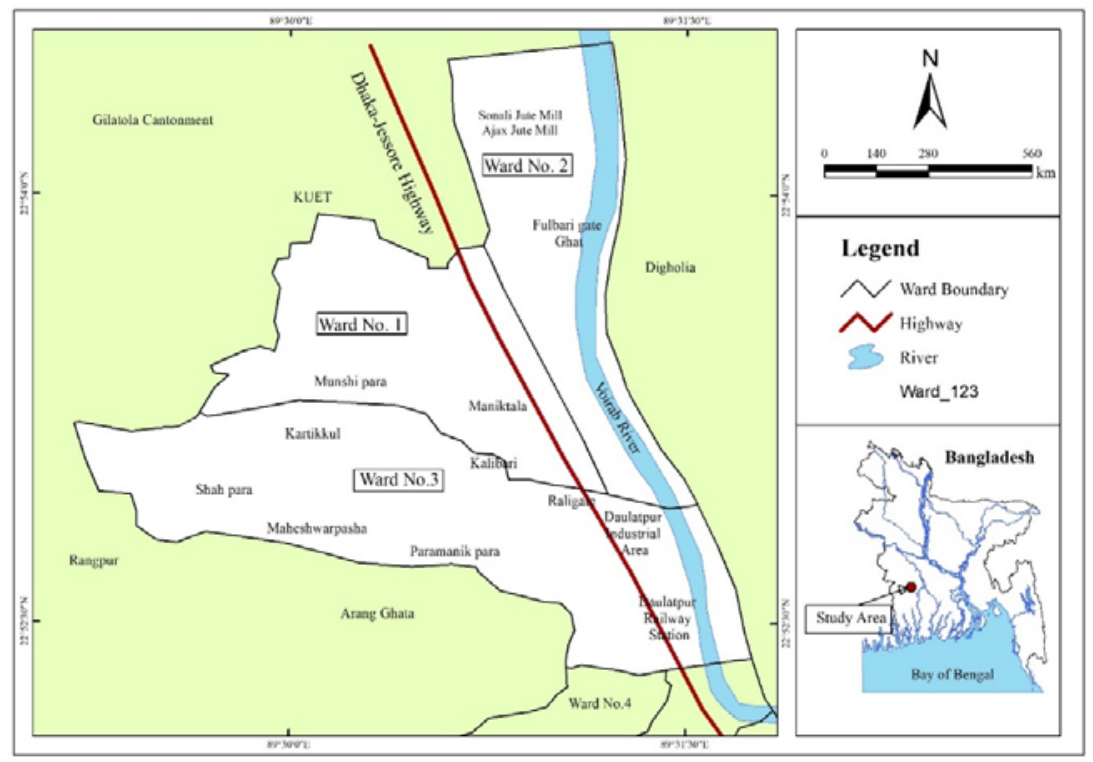

Figure 1: Location of study area; Source: KCC, 2019

The selected area (ward $1,2 \& 3$ ) is known as a residential area with a great amount of vegetation cover. Ward 2 is also renowned for the location of Bhairab River landing stage (at the eastern side of ward 2). Recently, like the prominent city Dhaka, Khulna city changed as a populated city (Azmain \& Rahman, 2018). In future the rate will increase as it is the center of the division and after the construction of the Padma bridge it will be turned as a super city. So, the dynamic change of land use seriously affects the environment now and in future. Islam et al., (2019) have done the analysis on urban heat island effect in Khulna city for a period of 17 years. The current study focused on a 9 years' time interval of 2010-2018, when a massive change in temperature happened in 2018, by focusing more on the massive after effect on environment due to the cause of greater change in the amount of vegetation cover in 2008 for Aila. The major jute mills of the north-western part of KCC are closed in 2012. Travel demand is $13 \%$ at the rail crossing of study area which is rising at a significant rate due to the location of a major university, Khulna University of Engineering \& Technology, bus stand and Fulbari gate market. So peak hour traffic congestion is most likely found over time (during the period of 2010-2018). The landing stage of Voirab River has drawn more people over the study period for the transportation of goods and individuals, for the purpose of work (sawmill, van stand by the river side), for the purpose of recreation (natural scenario by the river side).

\section{Data collection and preparation}

The natural extent of land cover and vegetation were explored with the help of LST and NDVI. On the perspective of the advancement in the contemporary technological field, remote sensing images were used in the current study. 
Aerial images were collected from the United States Geological Survey website, for the area which corresponds with ward no. 1, 2, 3 of KCC. Landsat 5 Thematic Mapper (TM) has 7 bands and of them band 6 is the thermal band. Band 6 from Landsat 5 was used for extracting the land surface temperature data. While Band 3 and band 4 were the visible red band and the infrared band, used for the NDVI calculation. Landsat 8 Operational Land Imager (OLI) and Thermal Infrared Sensor (TIS) images had 11 bands. Among those bands, the Red band (band 4) and Near Infrared band (band 5) are used for NDVI calculation. The TIR bands 10 was used for land surface temperature mapping (Long \& Srihar, 2004). Table 2 represents the specifications of Landsat 5 and Landsat 8 imageries, used for the research purpose (Chander \& Markham, 2003; Fensholt \& Proud, 2012; Li et al., 2013).

\section{Application of geospatial tools}

Land surface temperature data was extracted from the Landsat 5 imageries for the year 2010 and Landsat 8 imageries for the year 2018. Landsat 7 Science Data Users Handbook and Landsat 8 Data Users Handbook had detailed specifications of USGS formulas, to extract surface temperature data from Landsat 5 and Landsat 8 imageries, respectively (Avdan \& Jovanovska, 2016; Chander \& Markham, 2003). Raster calculator was used to execute the USGS formulas and some required values for the equation were gathered from the metadata file of Landsat $8 \mathrm{OLI}$ and TIS (value of ML, AL, K1 and K2 are given in Table 1). All the process, equation, list of variables from the USGS equations were specified in Table 1. After conducting the LST operation in ArcGIS, the research area was divided into some different LST classes (Table 1). The area under these classes (for NDVI calculation), the maximum, minimum and average temperature for ward 1,2 and 3 were calculated with the help of ArcGIS and MS Excel. Number of square units for each type of distinctive NDVI classes were multiplied by the area of one square unit ( 900 square meters $=30$-meter X 30 meter), to obtain the total area under each class (Table 3). The result of LST operation was in the form of raster which was further converted into vector format. The vector format data was further intersected with the ward boundary and then the vector format file was further exported into Excel. The exported data in Excel were used to calculate the maximum, minimum and the average temperature for ward 1, 2, 3 for the year 2010 and 2018 (Table 4).

\section{RESULTS \& DISCUSSION}

\section{Assessment of vegetation cover}

Table 3 demonstrates the vegetation health status as per the NDVI values for ward 1, 2 and 3 and the amount of corresponding land area for different types of vegetation cover. The area under low canopy and average canopy are zero for ward 1 and ward 2, where the amount of bare ground has been increased over the 8-consecutive year of study. By following the physical pattern of vegetation cover over the area (Figure 2a), most high values of NDVI were found by the residential area of ward 1, 2 and 3 (Maniktala, Banik para, Mallik para in ward 1; the residential area for the workers of Sonali Jute Mill and Ajax Jute Mill in ward 2; Kartikkul, Maheswarpasa, Parmanik para, Kaliibari, Islambag in ward 3). As the Dhaka-Jessore Highway passes by the area under study, low amount of NDVI value was found on the both side of the highway. NDVI value decreased on the western part of ward 3 (Figure 2b), as for the establishment of fish hatcheries by replacing the vegetation cover (western side of Kartikkul). A major portion of vegetation cover loss happened during the study period in ward 2. As the Sonali Jute Mill and Ajax Jute Mill closed down in 2012, people have to look for replacement job in sawmill by the side of Voirab river. So, the number of trees has decreased in ward 2 at a great extent (Table 3 ).

\section{Assessment of Land Surface Temperature}

Table 4 shows the average, minimum and maximum temperature data collected from the Landsat imagery analysis for the year 2010 and 2018. There are not much of temperature difference due to the adjacency of three wards. Among the three wards, ward 1 had slightly low temperature rather than ward 2 and ward 3 . Ward 2 has shown the highest temperature $32.5^{\circ} \mathrm{C}$ in the year 2018 . There are multiple factors to contribute for LST situation, like amount of greeneries, land use land cover pattern, amount and location of waterbodies. The spatial pattern of LST showed that the southeastern part of ward 3 has shown about highest temperature for the year 2010 and 2018 , where Raligate, Daulatpur industrial area, Daulatpur Railway station are located. A very busy portion of DhakaJessore Highway is located at this southeastern part of ward 3, which is a major crowded place of Khulna. People go on to Daulatpur for daily basis of work, for education (Government Daulatpur Muhsin High School), for shopping (Daulatpur bazar) and for passing by to go to Shib Bari or Dak-Bangla. 
Table 1: Specifications for Geo-spatial tools from Landsat 5 and Landsat 8 Imageries for the year 2010 and 2018

\begin{tabular}{|c|c|c|c|c|}
\hline $\begin{array}{l}\text { Landsat } \\
\text { Image }\end{array}$ & \multicolumn{2}{|c|}{ Process } & Equation & Variables specification \\
\hline \multirow{4}{*}{ 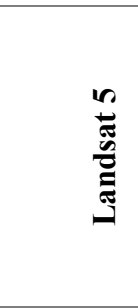 } & a) & $\begin{array}{l}\text { Conversion of the digital number } \\
(\mathrm{DN}) \text { to spectral radiance }(\mathrm{L})\end{array}$ & $\begin{array}{l}\mathrm{L} \lambda=\mathrm{LMIN}+(\mathrm{LMAX}- \\
\mathrm{LMIN}) \times \mathrm{DN} / 255\end{array}$ & $\begin{array}{l}\mathrm{L} \lambda=\text { spectral radiance of Band } 6, \mathrm{LMIN}=1.238, \mathrm{LMAX}=15.600 \text { and } \mathrm{DN}=\text { digital } \\
\text { number. }\end{array}$ \\
\hline & b) & $\begin{array}{l}\text { Conversion of spectral radiance to } \\
\text { temperature in Kelvin }\end{array}$ & $\begin{array}{l}\mathrm{TB}_{\mathrm{k}}=\mathrm{K} 2 / \ln [(\mathrm{K} 1 / \mathrm{L} \lambda)+ \\
1]\end{array}$ & $\begin{array}{l}\mathrm{K} 1=\text { Calibration Constant } 1(607.76), \mathrm{K} 2=\text { Calibration Constant } 2(1260.56) \text { for the } \\
\text { thermal band of the } \mathrm{TM} \text { data and } \mathrm{TB}_{\mathrm{k}}=\text { surface temperature in Kelvin. }\end{array}$ \\
\hline & c) & Conversion of Kelvin to Celsius & $\mathrm{TB}_{\mathrm{c}}=\mathrm{TB}_{\mathrm{k}}-273$ & $\mathrm{~TB}_{\mathrm{c}}=$ surface temperature in Celsius. \\
\hline & d) & NDVI Estimation & $\mathrm{NDVI}=\frac{N I R-R}{N I R+R}$ & NIR = Near Infrared Band (band 4), R = Red Band (band 3) \\
\hline \multirow{5}{*}{ 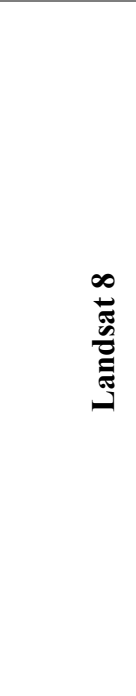 } & a) & $\begin{array}{l}\text { Conversion into Top of } \\
\text { Atmosphere (TOA) Radiance }\end{array}$ & $\mathrm{L} \lambda=\mathrm{ML} X \mathrm{Qcal}+\mathrm{AL}$ & $\begin{array}{l}\left.\mathrm{L} \lambda=\text { TOA spectral radiance (Watts/ }\left(\mathrm{m}^{2} \mathrm{X} \operatorname{srad} \mathrm{X} \mu \mathrm{m}\right)\right), \mathrm{ML}=\text { Band specific } \\
\text { multiplicative rescaling factor from the metadata }(0.00033420), \mathrm{AL}=\text { Band specific } \\
\text { additive rescaling factor from the metadata }(0.10000), \mathrm{Qcal}=\text { Quantized and calibrated } \\
\text { standard product pixel values }(\mathrm{DN})\end{array}$ \\
\hline & b) & $\begin{array}{l}\text { Conversion to Top of Atmosphere } \\
\text { (TOA) Brightness Temperature }\end{array}$ & $\begin{array}{l}\mathrm{BT}=\mathrm{K}_{2} / \ln \left(\mathrm{K}_{1} / \mathrm{L} \lambda+1\right) \\
-273.15\end{array}$ & $\begin{array}{l}\text { BT }=\text { Top of atmospheric brightness temperature }\left({ }^{\circ} \mathrm{C}\right), \mathrm{L} \lambda=\text { TOA spectral radiance } \\
\left(\text { Watts } /\left(\mathrm{m}^{2} \mathrm{X} \text { srad } \mathrm{X} \mu \mathrm{m}\right)\right), \mathrm{K}_{1}=\text { Band specific thermal conversion constant from the } \\
\text { metadata }=774.8853(\text { for band } 10), \mathrm{K}_{2}=\text { Band specific thermal conversion constant from } \\
\text { the metadata }=1321.0789 \text { (for band } 10)\end{array}$ \\
\hline & c) & NDVI Estimation & $\mathrm{NDVI}=\frac{N I R-R}{N I R+R}$ & NIR $=$ Near Infrared Band (band 5), $R=$ Red Band (band 4) \\
\hline & d) & Land Surface Emissivity (LSE) & $\begin{array}{l}\mathrm{PV}=\left(\frac{N D V I-N D V I \min }{\text { NDVImax }+N D V I \min }\right)^{2} \\
\mathrm{E}=0.004 \mathrm{X} \mathrm{PV}+0.986\end{array}$ & $\begin{array}{l}\mathrm{PV}=\text { Proportion of Vegetation, NDVI }=\mathrm{DN} \text { values from NDVI Image, NDVI }{ }_{\min }= \\
\text { Minimum DN values from NDVI Image, } \mathrm{NDVI}_{\max }=\text { Maximum DN values from NDVI } \\
\text { Image, } \mathrm{E}=\text { Land Surface Emissivity }\end{array}$ \\
\hline & e) & Land surface temperature (LST) & $\begin{array}{l}\mathrm{LST}=(\mathrm{BT} / 1)+(\mathrm{W}) \mathrm{X} \\
(\mathrm{BT} / 14380) \mathrm{X} \ln (\mathrm{E})\end{array}$ & $\begin{array}{l}\mathrm{BT}=\text { Top of atmosphere brightness temperature }\left({ }^{\circ} \mathrm{C}\right), \mathrm{W}=\text { Wavelength of emitted } \\
\text { radiance, } \mathrm{E}=\text { Land Surface Emissivity }\end{array}$ \\
\hline
\end{tabular}


Table 2. List of Landsat thematic mapper scenes used.

\begin{tabular}{ccccccc}
\hline Satellite & Acquisition date & Path/Row & Resolution (m) & Sun elevation & Azimuth & Cloud Cover \\
\hline Landsat 5 & $2010-02-06$ & $138 / 44$ & 30 & 41.83708911 & 140.90683281 & 0.00 \\
Landsat 8 & $2018-03-22$ & $138 / 44$ & 30 & 38.35907247 & 152.78285009 & 0.70 \\
\hline
\end{tabular}

Source: Metadata file of Landsat 8 Operational Land Imager (OLI) and Thermal Infrared Sensor (TIS)

Table 3. Vegetation Health Status and Corresponding Land Area (in square meter)

\begin{tabular}{lccccccc}
\hline \multirow{2}{*}{ Label } & Values & \multicolumn{2}{c}{ Area in square meter } & \multicolumn{2}{c}{ Area in square meter } & \multicolumn{2}{c}{ Area in square meter } \\
\cline { 3 - 8 } & & \multicolumn{2}{c}{ Ward 1 } & \multicolumn{2}{c}{ Ward 2 } & \multicolumn{2}{c}{ Ward 3 } \\
\cline { 2 - 8 } & & $\mathbf{2 0 1 0}$ & $\mathbf{2 0 1 8}$ & $\mathbf{2 0 1 0}$ & $\mathbf{2 0 1 8}$ & $\mathbf{2 0 1 0}$ & $\mathbf{2 0 1 8}$ \\
\hline Deep water & -1 to -0.1 & 900 & 0 & 3600 & 0 & 1800 & 0 \\
Light water & -0.1 to 0 & 24300 & 900 & 72000 & 1800 & 71100 & 19800 \\
Bare ground & 0 to 0.1 & 49500 & 35100 & 81000 & 72900 & 87300 & 69300 \\
Settlements & 0.1 to 0.2 & 63900 & 9900 & 51300 & 31500 & 113400 & 39600 \\
Very low canopy & 0.2 to 0.3 & 55800 & 53100 & 46800 & 45900 & 67500 & 86400 \\
Low canopy & 0.3 to 0.4 & 16200 & 0 & 8100 & 0 & 13500 & 2700 \\
Average canopy & 0.4 to 0.5 & 0 & 0 & 0 & 0 & 0 & 0 \\
\hline
\end{tabular}

Table 4. Status of Land Surface Temperature (in degree Celsius) for the year 2010 and 2018

\begin{tabular}{ccccccc}
\hline Ward no. & \multicolumn{3}{c}{2010} & \multicolumn{3}{c}{2018} \\
\cline { 2 - 7 } & Avg. & Min & Max & Avg. & Min & Max \\
\hline Ward 1 & 22.5 & 19.5 & 25.5 & 28.5 & 26.5 & 30.5 \\
Ward 2 & 22 & 17.5 & 26.5 & 30 & 27.5 & 32.5 \\
Ward 3 & 23.5 & 19.5 & 27.5 & 29 & 26.5 & 31.5 \\
\hline
\end{tabular}

So, the highest temperature is corresponded by high population density. On the south-western part of ward 3 , there are the residential area (Kartikkul, Maheswarpasa, Parmanik para, Kaliibari, Islambag) where temperature is the lowest due to the amount of vegetation cover over the area. Over the 8-consecutive year of study, ward 3 has greater amount of vegetation and waterbody rather than other two wards. As the Dhaka-Jessore Highway passing from ward 3 to the Northern part of the area under study, on the eastern side of which ward 2 is located, on the bank of River Voirab. The average temperature of ward 2 are found by the side of Dhaka-Jessore Highway, $22 \circ \mathrm{C}$ in 2010 (Figure 2c) and $30{ }^{\circ} \mathrm{C}$ in 2018 (Figure $2 \mathrm{~d}$ ). The maximum temperature of ward 2 is $26.5^{\circ} \mathrm{C}$ in 2010 , due to Sonali Jute Mill and Ajax Jute Mill, located at the Northern part of ward 2. The Jute Mills closed in the year 2012, which is the cause of high temperature area reduction on the Northern part of ward 2. But the maximum temperature has increased to $32.5^{\circ} \mathrm{C}$ for ward 2 for the year 2018. Due to the closure of the Jute Mills, some peoples' have moved from the area of ward 2 (decreasing settlement area found for the year 2018 from Table 3). Some people get engaged working in sawmill, located by the Voirab river side. So, the amount of vegetation decreased for the year 2018 (Table 3). The 
eastern most part of ward 2 (by the river side), the minimum temperature for ward 2 are found during the year 2010 and 2018.

Comparing with ward 2 and ward 3, ward 1 has the low level of temperature for the study period. Under the influence of waterbody and vegetation cover in ward 1, the maximum temperature is found by the side of DhakaJessore Highway for both the year 2010 and 2018. The western and middle portion of ward 1 are occupied with residential area (Maniktala, Banik para, Mallik para) with a lot of greeneries and fish hatcheries. There is only one small plastic industry by the side of Khulna City Bypass road, on the northern part of ward 1.

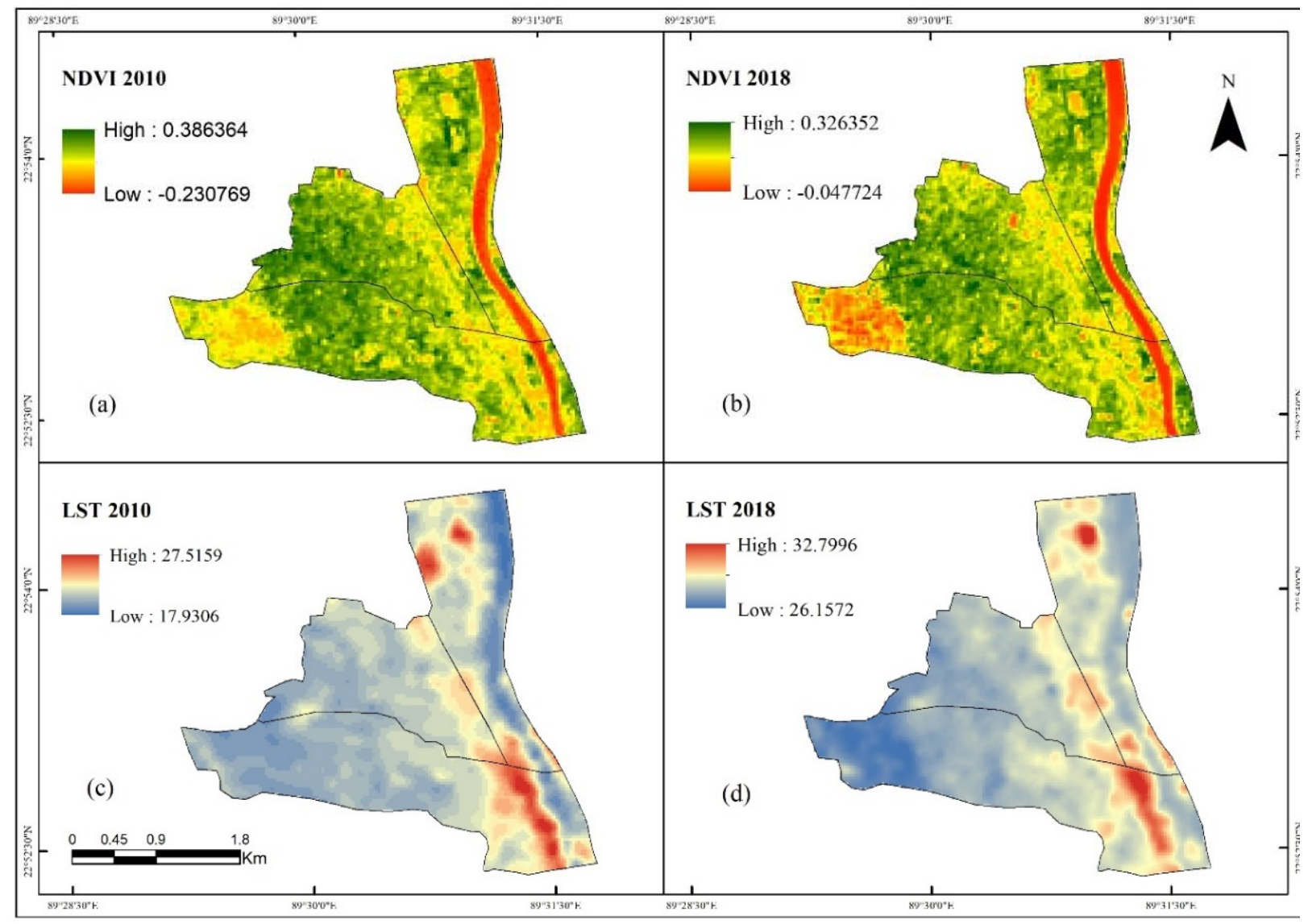

Figure 2. (a) NDVI for 2010, (b) NDVI for 2018, (c) LST for 2010, (d) LST for 2018; Source: Author, 2019

\section{CONCLUSION}

The overall vegetation has decreased in the year 2018 from the year 2010, parts of the study area had faced increasement in amount of vegetation which helped in decreasing the temperature eventually (for ward 3 in year 2018). Moreover, other factors like presence of waterbodies also have an important role in reducing surface temperature (for ward 1). The study was conducted in the north-western part of the large city corporation. So, the scenario for the whole city might have some differences which is a limitation of the study. More and vast studies are required to find the scenario of the whole city or the country. Again, as the presence of other factors seemed to have impact on the 
temperature, further studies can be conducted to see if other factors are more impactful in this case. However, the paper might work as a framework for future studies related to vegetation and temperature monitoring in regard of environmental studies. Again, it will also serve as a document for understanding the factors associated with the changing pattern and trends of surface temperature of the area under study and the area adjacent areas with similar specifications.

\section{REFERENCES}

Anandababu, D., Purushothaman, B. M., \& Suresh Babu, S. (2018). Estimation of Land Surface Temperature using LANDSAT 8 Data. International Journal of Advance Research, 4(2), 177-186.

Avdan, U., \& Jovanovska, G. (2016). Algorithm for Automated Mapping of Land Surface Temperature Using LANDSAT 8 Satellite Data. (G. Tian, Ed.) Journal of Sensors, 2016. Retrieved from http://dx.doi.org/10.1155/2016/1480307

Azmain, M., \& Rahman, M. (2018). Influences of Tranportation System on Land Use and Predicting the Changes in Khulna Metropolitan Area, Banglaedesh. International Journal of Scientific \& Engineering Research, 9(9), 286-293.

Babu, C. M., Hemalatha, T., \& Naik, B. R. (2016). Comparison of remote sensing-based indices for drought monitoring in Anantapur. International Journal of Applied Research, 2, 449-456.

BBS. (2011). Population \& Housing Census 2011. Bangladesh Bureau of Statistics.

Chander, G., \& Markham, B. (2003). Revised Landsat-5 TM Radiometric Calibration Procedures and Post calibration Dynamic Ranges, IEEE Transactions on Geoscience and Remote Sensing, 41(11), 2674-2677.

Deng, Y., Wang, S., Bai, X., Tian, Y., Wu, L., Xiao, J., Chen, F., \& Qian, Q. (2018). Relationship among land surface temperature and LUCC, NDVI in typical karst area. Scientific Reports, 8, 641.

Esha, E. J., \& Ahmed, A. (2018). Spatio-Temporal Assessment of the Impact of Land Cover Change in the NorthWest Region of Bangladesh. Proceedings of the 4th International Conference on Civil Engineering for Sustainable Development (ICCESD 2018), KUET, Khulna, Bangladesh.

Fathizad, H., Tazeh, M., Kalantari, S., \& Shojaei, S. (2017). The investigation of spatiotemporal variations of land surface temperature based on land use changes using NDVI in southwest of Iran. Journal of African earth science, 134, 249-256.

Fensholt, R., \& Proud, S.R. (2012). Evaluation of Earth Observation based global long term vegetation trendsComparing GIMMS and MODIS global NDVI time series. Remote Sensing of Environment, 119, 131-147.

Grover, A., \& Singh, R. B. (2015). Analysis of Urban Heat Island (UHI) in Relation to Normalized. Environments, 2, 125-138.

Guha, S., \& Govil, H. (2020). An assessment on the relationship between land surface temperature and normalized difference vegetation index. Environment, Development and Sustainability, 22. https://doi.org/10.1007/s10668020-00657-6

Islam, K. S., Islam, M. D, Chakraborty, T., \& Alam, M. D. (2019). Urban Heat Island Effect Analysis Using Integrated Geospatial Techniques : a Case Study on Khulna City, Bangladesh. Proccedings of International Conference on Climate Change (ICCC-2019), Dhaka, Bangladesh.

Jiang, Z., Huete, A. R., Chen, J., Chen, Y., Li, J., Yan, G., \& Zhang, X. (2006). Analysis of NDVI and scaled difference vegetation index retrievals of vegetation fraction. Remote Sensing of Environment, 101(3), 366-378. https://doi.org/10.1016/j.rse.2006.01.003

Kovalev, A., \& Tokareva, O. (2016). Using MODIS NDVI products for vegetation state monitoring on the oil production territory in Western Siberia. Proceedings of MATEC Web of Conference. Siberia: EDP Sciences.

Li, J., Liu, Y., Cao, M., \& Xue, B. (2015). Space-Time Characteristics of Vegetation Cover and Distribution: Case of the Henan Province in China. (M. A. Rosen, Ed.) Sustainability, 7, 11967-11979. doi:10.3390/su70911967

Long, W., \& Srihar, S. (2004). Land Cover Classification of SSC Image: Unsupervised and Supervised Classification Using ERDAS Imagine. Proceedings of the International Geoscience and Remote Sensing Symposium (IGARSS) (pp. 2707-2712). Petersburg, VA, USA.

Mia, B., Bhattacharya, R., \& Woobaidullah, A. S. M. (2017). Correlation and Monitoring of Land Surface Temperature, Urban Heat Island with Land use-land cover of Dhaka City using Satellite imageries. International Journal of Research in Geography, 3(4), 10-20. https://doi.org/10.20431/2454-8685.0304002.

Mondal, C., \& Uddin, J. (2018). Study of Land Surface Temperature Changes in Selected Drainage Basin of AtaiBhairab-Rupsha River Based on Ndvi and Ndwi Analysis. Proceedings of the 4th International Conference on 
Civil Engineering for Sustainable Development (ICCESD 2018), KUET, Khulna, Bangladesh.

Paruelo, J.M., Epstein, H.E., Lauenroth, W.K., \& Burke, I.C. (1997). ANPP estimates from NDVI for the central grassland region of the United States. Ecology 1997, 3, 953-958.

Raynolds, M.K., Comiso, J.C., Walker, D.A., \& Verbyla, D. (2008). Relationship between satellite-derived land surface temperatures, arctic vegetation types, and NDVI. Remote Sensing of Environment, 112, 1884-1894.

Saha, M., Paul, B., Gupta, A., \& Saha, S. (2016). Environmental Impact Assessment and Planning Through Geospatial Technique - An Integrated Approach in A Coal Mining Block of Jharia Coalfield. Proceedings on $6^{\text {th }}$ Asian Mining Congress. Kolkata, India.

Shimu, S. A., Aktar, M., Afjal, M. I., Nitu, A. M., Uddin, M. P., \& Al Mamun, M. (2019). NDVI Based Change Detection in Sundarban Mangrove Forest Using Remote Sensing Data. Proceedings 4th International Conference on Electrical Information and Communication Technology (EICT), Khulna, Bangladesh.

Song, Z., Li, R., Qiu, R., Liu, S., Tan, C., Li, Q., Ge, W., Han, X., Tang, X., Shi, W., Song, L., Yu, W., Yang, H., \& Ma, M. (2018). Global land surface temperature influenced by vegetation cover and PM 2.5 from 2001 to 2016. Remote Sensing, 10(12), 1-18. https://doi.org/10.3390/rs10122034

Tashnim, J., \& Anwar, A. (2016). Reasons and Remides of Heat Island Phenomena for Dhaka City: A Review. Proceedings of the 3rd International Conference on Civil Engineering for Sustainable Development (ICCESD 2016) (pp. 228-234). KUET, Khulna, Bangladesh.

Tran, D. X., Pla, F., Latorre-Carmona, P., Myint, S. W., Caetano, M., \& Kieu, H. V. (2017). Characterizing the relationship between land use land cover change and land surface temperature. ISPRS Journal of Photogrammetry and Remote Sensing, 124, 119-132.

Uddin, M. J., \& Mondal, C. (2020). Effect of Earth Covering and Water Body on Land Surface Temperature (LST). Journal of Civil Engineering, Science and Technology, 11(1), 45-56. https://doi.org/10.33736/jcest.2065.2020

Wang, X., Piao, S., Ciais, P., Li, J., Friedlingstein, P., Koven, C., \& Chen, A. (2011). Spring temperature change and its implication in the change of vegetation growth in North America from 1982 to 2006. Proc. Natl. Acad. Sci. USA, 108, 1240-1245.

Weier, J., \& Herring, D. (2000). Measuring Vegetation (NDVI \& EVI). Journal of Geoscience and Environment Protection. 5(8). Nasa Earth Observatory, Washington DC. Retrieved June 2019, from NASA Earth Observatory: https://earthobservatory.nasa.gov/features/MeasuringVegetation.

World Population Review. (2019). Population of Cities in Bangladesh (2019). Retrieved from World Population Review: http://worldpopulationreview.com/countries/bangladesh-population/cities/

Zhao, S., Cong, D., He, K., Yang, H., \& Qin, Z. (2017). Spatial-temporal variation of drought in China from 1982 to 2010 based on a modified Temperature Vegetation Drought Index (mTVDI). Scientific Reports, 7, 17473. 